\title{
Porozumění vědnímu oboru a předmětu jeho zkoumání neboli nehrdinská historie etnologie a antropologie v Litvě
}

\author{
Auksuolè Čepaitiené
}

DOI: $10.21104 / C L .2016 .2 .02$

\section{Understanding a Discipline and its Object or the Unheroic History of Ethnology and Anthropology in Lithuania}

\begin{abstract}
Anthropological practices are local in craft, intellectual and disciplinary tradition, and they are just as different. The article will discuss the ways in which ethnology and anthropology are understood, constitute their identity in Lithuania in historical retrospection and among the spectrum of scientific domains, and which aspects appear significant in the process of their institutionalization. It highlights the historical roots of ethnology and anthropology in Lithuania traced to the intellectual environment of Vilnius University of the late 18th century and early 19th century; emphasizes the influences of cultural evolutionism and the Vienna school; discusses the efforts to institutionalize the disciplines within the contemporary politics of science in Lithuania; and claims of the disciplines for the future. The article concludes with an emphasis on the methodological value of ethnography that witnesses the vitality of ethnological and anthropological thought in Lithuania, and affirms the paradigmatic
\end{abstract}

uniqueness of ethnology and anthropology among the spectrum of sciences.

Keywords disciplining, history of ethnology and anthropology, ethnography as methodology, classificatory systems of science, Lithuania.

Contact Dr. Auksuolè Čepaitienè, Department of Ethnology and Anthropology, Lithuanian Institute of History, Kražių g. 5, LT-01108 Vilnius, Lithuania; e-mail: auksuole. cepaitiene@istorija.It.

Jak citovat / How to cite Čepaitienè, Auksuolè. (2016). Porozumění vědnímu oboru a předmětu jeho zkoumání neboli nehrdinská historie etnologie a antropologie v Litvě. Český lid 103, 181-197. doi:http:// dx.doi.org/10.21104/CL.2016.2.02 
Je zřejmé, že antropologie a s ní související disciplíny rozvinuté v moderní vědní obory přispívají ke kritickému povědomí o kulturních a společenských složitostech lidských záležitostí a světů. Mobilita současného života plná nečekanosti, nejistoty a změn nabízí mnoho témat ke sledování, čas od času dokonce vybízí k návratu na místa, která už jsou dobře známá. Od pádu Sovětského svazu a Berlínské zdi učinila etnologie a antropologie ve střední a východní Evropě velký posun v nejrůznějších ohledech, včetně disciplinárního členění. Změny probíhaly nejrůznějšími směry a pod nejrůznějšími perspektivami, jedna věc se však ukázala naprosto jasně - tento rozlehlý geografický prostor není ani tak monolitický, ani tak homogenní, jak naznačovaly předchozí geopolitické studie (Berdahl 2000; Hann 2007).

Antropologové tvrdí, že antropologické metody se místo od místa liší, at už ve způsobu provádění, nebo v intelektuální a oborové tradici. Jedním z takových případů je i způsob vývoje etnologické a antropologické epistemologie v Litvě. Zrod a přerušování zdejší intelektuální tradice, její přehodnocování a nové vymezování probíhaly v souladu s historickými a politickými změnami, složitostmi, potřebami a vizemi společnosti posledních dvou staletí.

Institucionalizaci etnologie a antropologie v Litvě se věnovala už řada odborníků (Ciubrinskas [Čiubrinskas] 2015; 2001, Šaknys 2011; Savoniakaitė 2008a; 2008b; Apanavičius 2009; Milius 1993; Merkienẻ 2011; Dundulienė 1978 a další.). Ovšem vědecká identita a institucionální místo antropologie a etnologie nadále zůstávají nejisté a okrajové, daným oborům se i v současnosti věnuje jen velmi málo vědců. Bez ohledu na řadu kroků podniknutých od 90. let jsou tyto disciplíny nadále zpochybňovány dalšími oblastmi výzkumu. Nicméně jejich rozvoj nadále zůstává na programu a vyvolává vážné debaty v akademické komunitě i mezi samotnými etnology a antropology. Tudíž znovu vyvstává otázka, ne nepodobná té, kterou kdysi položil Martyn Hammersley (Hammersley 2001): Co se to děje s etnografií, etnologií a antropologií? Přesněji řečeno: Co se to s nimi děje v Litvě?

V tomto článku se věnujeme způsobům, jakými jsou etnologie a antropologie v Litvě vnímány jako vědní obory a jaké aspekty měly významný vliv při procesu jejich institucionalizace. Bohatým zdrojem pro diskuzi je i pohled zpět do minulosti. K antropologii a etnologii přistupujeme jako k př́buzným disciplínám a ponecháváme stranou otázky jejich soupeření, kterým se věnoval už Čiubrinskas (Ciubrinskas 2015). Obě nám poskytují znalosti potřebné pro kulturní pochopení lidských světů a lidského chování. Litevský přístup je zastoupený periodikem Lithuanian Ethnology: Studies in Social Anthropology and Ethnology.

Pokud jde o pojmosloví, článek bere v úvahu, jakým způsobem k rozdělování jednotlivých vědních oborů, tedy tzv. „disciplining“, přistupuje James Clifford (Clifford 2005). Clifford tvrdí, že v jádru vědního oboru jsou čtyři základní teoreticko-praktické složky - předmět, metoda, paradigma a télos. Podle něj se během prvních 75 let 20. století antropologická komunita dokázala 
shodnout na jejich následujícím stanovení: „předmětem jsou ,primitivní společnosti, metodou je ,práce v terénu', paradigmatem ,kultura‘ a télosem ,člověk““ (Clifford 2005: 37). V dnešní době však je toto vymezení zpochybňované a už se nepovažuje za tak přirozené jako dříve - antropologie prožívá období nového členění (Clifford 2005: 40-45). Pro diskuzi v článku má velký význam rovněž postřeh Alberta Jiméneze, že znalosti jsou ve společnosti utvářeny a předávány prostřednictvím správy (Jiménez 2007). Tato správa se týká vnitřních i vnějších perspektiv, díky ní je vědní odbor viditelný ve společnosti i v rámci vědecké komunity. Nicméně se zdá, že pro porozumění vývoji členění jednotlivých disciplín je důležitý i ohled na „paradigmatickou tradici“, která se týká místních historických a intelektuálních zájmů i antropologie jako takové a nastínil ji Georg Stocking (Stocking 1992).

Článek začíná historickými základy, které je možné vystopovat až do konce 18. a počátku 19. století, kdy se v intelektuálním prostředí Vilniuské univerzity objevily antropologické a etnologické pojmy a antropologické uvažování. Zde bychom chtěli upozornit zejména na vliv kulturního evolucionismu a Vídeňské školy, ale také na stav tohoto oboru ve 20. a 30. letech 20. století. Článek dále ukazuje, jak je postavení disciplíny utvářeno vědeckou politikou a formálními záležitostmi klasifikačních systémů vědních oborů. I když současná věda klade velký důraz na technologický rozvoj a výzkum a vývoj, strategie společenských a humanitních věd s antropologií, etnologií a folkloristikou jako třemi samostatnými obory nadále trvá na udržitelnosti tohoto pojetí do budoucnosti. V závěru článek klade důraz na metodologický př́ínos etnografie pro udržení disciplinární identity etnologie i antropologie v Litvě, kterou jasně ukázala jejich rozštěpená minulost a praxe.

\section{Historické základy}

Kořeny etnologické a antropologické epistemologie v Litvě můžeme vystopovat až k intelektuálnímu prostředí Vilniuské univerzity konce 18. a počátku 19. století (Maciūnas 1939; Dundulienè 1978). Přelom 18. a 19. století bylo dramatické období plné politických i společenských změn, ztráty státnosti v roce 1795, ale zároveň i rozvoje vědeckého myšlení a řady vědních oborů, objevení ,jinakosti“, místního rolníka, tedy představitele původní ,jiné kultury“, „lokální exotiky“ a zajímavého předmětu zkoumání (viz také PosernZieliński 1995; Wyngaard 2004; Čepaitienè 2011). Na tehdejší intelektuální prostř̌edí Vilniuské univerzity měly velký vliv rovněž myšlenky osvícenství a francouzské ekonomické teorie fyziokratizmu. Zásada fyziokratů, že národní bohatství a ekonomická životnost společnosti pochází z místních zdrojů, prírodních zákonů, soukromého majetku, individualismu a laisser faire, společenský význam rolnictva a jeho vzdělávání, zemědělství a práce jako zdroj hodnot (viz také Jučas 1997) v Litvě vzbudily mimořádnou pozornost věnovanou vědě a pozorování zaměřenému dovnitř (viz také Savoniakaitė 2008b). 
Intelektuální prostředí Vilniuské univerzity bylo navíc kontextem, kde došlo k paradigmatickému obratu v kulturním uvažování o lidských fenoménech.

První událostí poukazující na počátek antropologického a etnologického uvažování je příspěvek př́rodovědce, autora cestopisů a etnologa George Forstera, který se účastnil druhé výpravy kapitána Jamese Cooka kolem světa v letech 1772-1775. Forster byl pozván, aby vedl Katedru přírodní historie (Historiae naturalis) na Vilniuské univerzitě, měl zde také zkoumat místní prrírodní zdroje a zhodnotit ekonomickou, zemědělskou a medicínskou hodnotu místní vegetace (Švambarytė 2009). Mezi lety 1784-1787 rovněž vedl kurzy botaniky, mineralogie a zoologie, kam zařazoval i kapitoly z paleontologie, antropologie a etnografie, sbíral vzorky v okolí Vilniusu a při přednáškách pro místní veřejnost povzbuzoval zájem o univerzálnost přírodní historie, empirické pozorování a sběr (Kudaba 1988). Během svého pobytu na Vilniuské univerzitě Forster sepsal nástin svého díla Neuholland und die brittische Colonie in Botany-Bay (Nové Holandsko a britská kolonie v Botany Bay, 1786), článek, v němž debatoval s Immanuelem Kantem o pojmu rasy (Noch etwas über die Menschenrassen, 1786) a další práce.

Druhou významnou událostí bylo založení katedry historie na Vilniuské univerzitě v roce 1783 a teoretický rozvoj historie, za který vděčíme absolventu Vilniuské univerzity a radikálnímu levičákovi Joachimu Lelewelovi (viz také Norkus 2015). Lelewela ovlivnili Voltaire, Adam Ferguson, David Hume, Johann Gottfried Herder, Immanuel Kant, William Robertson, Leopold von Ranke, Friedrich Rühs, Johann Ernst Fabri a další a historii vnímal v širším smyslu jako obecný stav bytí lidských bytostí, společností a přírody v čase (Lelewel 1815: 34; 1964). Podle jeho názoru mají antropologické, etnologické a etnografické znalosti metodologický význam pro objasnění historie daného národa. Ve svém díle Historyka tudzież o łatwem i pożytecznem nauczaniu historyi (Historyka neboli snadné a užitečné učení historie) o metodologii historie, která byla vydána ve Vilniusu v roce 1815 (Lelewel 1815), uvedl rovněž definice antropologie, etnologie a etnografie. Antropologii a etnologii chápe jako prostředky k odhalení spojitostí (mezi národními svazy a národy) týkajících se tělesné formy a stavby, původu jazyků, náboženství a různých postojů zděděných po předcích, úrovně dokonalosti těla a vitality ducha, jazykové vytříbenosti, schopností mysli a národního charakteru, který umožňuje rozpoznat schopnosti a sklony, důvody, zásady a vzájemné propojení (Lelewel 1815: 34-35). Etnologie je podle jeho názoru srovnatelná s historickou antropologií, zatímco etnografie je přehledem stavu lidských záležitostí v daném okamžiku, tudíž je vlastně podoborem historie (Lelewel 1964: 101, 143-145, 282). Navíc byl toho názoru, že historie souvisí s geografií nebo politickou geografií a statistikou a že její hlavní složkou jsou mapy (Norkus 2015).

Třetí významnou událostí je kniha Antropologia o własnościach człowieka fizycznych i moralnych (Antropologie tělesných a morálních vlastností lidské bytosti) od Józefa Jasińskiho, lékaře, chirurga a fyziokrata, absolventa 
Lékařské fakulty Vilniuské univerzity, která vyšla ve Vilniusu v roce 1818 (Tunaitis 2004; Jasiński 1818). Tato kniha se s velkou pravděpodobností inspirovala dobře známým dílem Ernsta Platnera Anthropologie für Aerzte und Weltweise (Antropologie pro lékaře a světaznalé), 1772, což autor zmiňuje v úvodu. Jasiński v knize čtenáře seznamuje s pojmem antropologie, definuje ji jako vědu věnující se tělesným a morálním vlastnostem člověka, které určují jeho hodnotu a nadřazují ho jiným fyzickým bytostem. Člověk je považován za organickou, sociální a psychologickou bytost: tělesné projevy organického života ho spojují se zemí, zároveň však cítí potřebu spojit se se společností, v níž se narodil, kde žije, vyvíjí se a v níž kvưli svým základním potřebám musí i setrvat, lidská pouta vznikají v bolesti. Při popisu společenských aspektů mluví Jasiński o vztahu mezi zvykem a normou a zmiňuje Rousseaua a Montesquieua. Za základní lidskou potřebu považuje obstarávání potravy a rozlišuje čtyři prapůvodní stadia lidské pospolitosti: sběr, rybolov a lov, pastevectví a zemědělství (Jasiński 1818: V-XX, 47-55).

Všechny tyto př́ípady poukazují na počáteční vliv německých antropologických a etnologických idejí, francouzského a skotského osvícenství a voltairovského pojetí historie a objev kulturního hlediska (viz také Eriksen a Nielsen 2001: 1-19). Antropologické a etnologické uvažování se zde objevuje v kontextech přírodní historie, historie a lékařské vědy - tedy v rámci př́rodních, společenských i humanitních věd, které Stocking nazývá „deštníkové uspořádání“ a jež používají i současní antropologové (Stocking 1992: 342). Podobné pojetí těchto disciplín se vztahuje k univerzalistickému stylu myšlení o povaze lidstva a dnešním jazykem řečeno obsahuje aspekty multi-, inter- nebo dokonce protodiciplinárního uvažování. Velmi důležitý je fakt, že univerzalistický přístup k etnologii v Litvě přetrval i v 19. a 20. století a jeho hlavním zájmem bylo poznání země a jejích obyvatel.

Pro přelom 18. a 19. století je rovněž charakteristický pozitivistický př́ístup a velká obliba sběratelství. Profesoři Vilniuské university, studenti i amatéři se účastnili sběru poznatků, „zvyků“ a vzorků. Byl to naprosto nový druh společenské činnosti, podobně jako terénní výzkum, založený na rozdílu mezi pozorováním běžným a pozorováním vědeckým, které zavedlo osvícenství a bylo dále rozvinuto odcizováním dobře známého a přibližováním cizího (viz také Gow 2009; Spiro 1991; Čepaitienė 2011). Původní, etnické znalosti se staly předmětem pozorování a shromažd’ování a byly považovány za empirický materiál vhodný pro rozvoj věd, jako je historie, jazykověda, literatura, právo a statistika, ale také fyziky, geologie, geografie, medicíny a zemědělství. Tehdejší dobové dotazníky, poznámky a publikace ve vědeckých časopisech ve Vilniusu poukazují na vědeckou hodnotu venkovských lidových zvyků a artefaktů. Znalosti, které z nich byly čerpány, byly konceptualizovány v rámci myšlenek starobylosti, porovnávání a pokroku: „Chceme-li získat znalosti z našich obyčejů a starodávných tradic a odhalit jejich podobnost se starými národy, musíme poznat lidové obyčeje ze všech provincií, vojvodství a okresư“ ([Szydłowski] 1819). 
Jako první přilákaly pozornost lidové písně a svatební obyčeje. Nicméně akademický život i činnosti byly přerušeny v roce 1832, kdy po povstání z roku 1831 došlo k uzavření Vilniuské univerzity. ${ }^{1}$

Zájem o etnologii a antropologii se znovu objevil koncem 19. století v období litevského národního obrození, kdy se v rámci národní konsolidace hodnotily jazyk, kultura a sebeuvědomění. Obrysy národní identity byly stanoveny v souladu s „hodnotou etnografického práva“ (Klimas 1917). Etnologie, a zvláště pak etnografie skutečně získaly politické zabarvení v herderiánském smyslu (viz také Ciubrinskas 2015), avšak nejen v něm. Litevská vědecká společnost (Lietuvių mokslo draugija), ${ }^{2}$ která byla založena v roce 1907, měla za cíl zkoumání národa a jím obývaného území. Její zakladatel Jonas Basanavičius, lékař a člen Vídeňské antropologické společnosti, který se věnoval výzkumům v oblasti fyzické antropologie, etnografie a folkloru, v zahajovacím projevu pronesl, že litevská věda stále ještě čeká na studie antropologického, etnologického, etnografického, archeologického a dalších zaměření. I když se do společnosti začlenily společenské i přírodní vědy, v prvním článku jejích stanov se uvádělo, že jejím cílem je studium antropologie a etnografie Litvy (Milius 1993). Folklorní komise společnosti vydala v roce 1910 program Trumpa folklioro dalykams rinkti programa podněcující ke sbírání folklorního materiálu, a to včetně hmotných artefaktů. Tento program zaměřoval pozornost na zvyky, víru, ústní tradici a př́běhy o přírodních jevech, přízracích, rituálech životního cyklu, narození a smrti, povolání a běžný denní život, lidové léčitelství, zvykové právo a svátky. Způsob systematizace byl převzat z knihy Ethnology in Folklore (Etnologie ve folkloru) z roku 1892 od britského folkloristy George Lawrence Gomma, která byla do polštiny přeložena v roce 1901 jako př́ručka pro studenty folkloru - Folklor: podręcznik dla zajmujących się ludoznawstwem. Gomme spolu s Edwardem B. Tylorem v Británii patřil k vlivným představitelům kulturního evolucionismu, avšak zaměřil se na oblast folkloru. Jeho teoretické myšlenky, metodologické př́stupy a dovnitř zaměřený úhel pohledu nepochybně vzbudily kladnou odezvu mezi těmi, kdo se v Litvě snažili rozvinout vědecké povědomí. Jeho myšlenky o „přežití starých tradic a přesvědčení“, „rolnické kultuře“, folkloru jako historické vědě a etnologii ve folkloru jsou reflektovány v dílech litevských etnografů a folkloristů a v tehdejší vědecké tradici litevské etnologie.

Etnologie, antropologie a etnografie obecně byly považovány za zkoumání kultury a obyvatel světa v jejich fyzické, sociální a kulturní formě. 
Rozsáhlé dílo Ethnologija arba mokslas apie žemės tautas (Etnologie, neboli věda o lidech této země) vyšlo v roce 1903 v litevštině, v Chicagu a získalo litevskou medaili na světové výstavě Exposition Universelle v Paříži roku 1900. Kniha je etnografickým přehledem lidských skupin a ras všech kontinentů. Její vydavatel ji sestavil a přeložil z děl Michaela Haberlandta a Charlese Jeana-Marieho Letourneaua. Definice etnologie z této knihy je jen mírně upravenou verzí Haberlandtovy definice z díla Ethnologie vydaného roku 1900: „Etnologie je věda, která se seznamuje s většími či menšími skupinami lidských bytostí rozmístěnými po celém světě a popisuje ,vzhled“ a duševní vlastnosti nejrůznějších národních skupin žijících po celé zemi.“ (Šernas 1903: 3) Letourneauovy myšlenky o rozdílech mezi lidmi a politické evoluci lidské rasy byly zpracovány studenty Univerzity Vytautase Velkého v Kaunasu (např. Leonas 1995 [1939]: 3). Období 20. a 30. let 20. století bylo dobou institucionalizace věd jako studijních oborů na univerzitách a antropologie s etnologií byly veřejnosti představeny články v časopisech Kultūra (Kultura), Kosmos nebo Gimtasai kraštas (Rodná země) (např. Endziulaitytė-Gylienė 1926; Končius 1934). Přemýšlelo se o disciplínách jako takových, např́íklad Pierre Broca antropologii považoval za historii původu člověka.

„Nicméně Brocovo pojetí antropologie může být rozšířeno a chápáno šíreji nebo naopak úžeji. Antropologie se kvůli povaze předmětu zkoumání štěpí na dvě části, na fyzickou, tedy antropologii $v$ zúženém smyslu, a psychickou (mentální), kterou chápeme jako etnologii a etnografii. [...] Cílem psychické antropologie je zkoumání duševního života sociálních skupin (národů, tříd). [...] Oblasti zkoumání mentální antropologie jsou definovány hranicemi primitivních kultur, protože historie rozvinutějších kultur už připadá vědám vzniklým před dávnými roky, např́klad historii, kulturní historii a dalším." (Endziulaitytè-Gylienè 1926: 156-157)

Antropologie byla definována jako studie lidských bytostí a lidských ras - živých organismů - s hlavní pozorností zaměřenou na vnější prvky a hledání podobností a rozdílů (Končius 1934). Byla považována za obor příbuzný s fyzickou antropologií, prehistorií, primatologií, psychologií, sociální antropologií, etnologií, etnografií, archeologií, srovnávací lingvistikou, srovnávací mytologií a antropogeografií, ale také geografií, kulturní historií, sociologií nebo hygienou. Etnologie pak byla chápána jako zkoumání složitých souvislostí a rozdílů mezi různými národy, které zahrnovaly vnější rysy, denní život, kulturu a životní podmínky (Končius 1934). Etnologický program pro shromažd’ování litevských znalostí a historických památek v rámci zkoumání národa (Lietuviu tautotyros žinių ir senienu rinkimo programa, 1925) od Petrase Būtėnase zahrnoval i geografické a historické otázky; statky, budovy a jejich interiéry; odívání a šperky; jídlo a pití; životní styly; řemesla a zaměstnání; rodinu, rituály 
a další národní rysy; staré bohy a přesvědčení (a kalendářní svátky); jazyk a lidskou tvořivost; zvykové právo; používané technologie; popis říčních koryt; nápisy na hrobech; shromažd’ování materiální kultury; litevské národní sporty (Būtènas 1925). V tomto programu se místo výrazu „etnografické znalosti“ („etnografijos (tautotyros)“ žinios) používá tautotyra („zkoumání národa“) odpovídající německému pojmu Volkskunde nebo polskému ludoznawstwo (Čepaitienė 2014). Později se začal používat další výraz etnika („etnická studia“). Oba zohledňují multidisciplinární nebo interdisciplinární přístup, který může být chápán, když použijeme parafrázi Spirových slov, jako „etnověda o litevské kultuře“ (Spiro 1991: 9). Etnografie pak byla definována jako zkoumání vzdálených, primitivních a exotických světových kultur a ras.

A měli bychom zdůraznit ještě jeden aspekt. Disciplinární identita etnologie, etnografie a antropologie byla ve 20 . a 30. letech 20 . století ovlivněna dvěma školami a teoriemi - kulturním a sociálním evolucionismem a Vídeňskou etnologickou školou s jejími myšlenkami o vývoji a místě, starém a typickém. Dopady těchto teorií ovlivnily vědu jako takovou, ale jistým způsobem také porozumění jednotlivým disciplínám.

Johannes Fabian ve své práci Time and the Other: How Anthropology Makes its Object hovoří o nároku antropologie na moc, který vychází z jejích kořenů, a říká, že neexistuje poznání o „jiném“, které by zároveň nepodléhalo časovým, historickým a politickým aspektům (Fabian 1983: 1). Cituje J. M. Degéranda, který hovoří o filozofickém cestovateli, který se plaví na konec světa, ale ve skutečnosti cestuje v čase a zkoumá minulost, přičemž každý krok, který učiní, znamená uplynutí jedné éry. Fabian jde dále v evoluci a prostorové naturalizaci času a uvádí, že vztahy mezi částmi světa jako přirozenými a sociokulturními jednotkami jsou chápány v rámci časových vztahů - rozptýlení v prostoru ve skutečnosti odráží sled v čase (Fabian 1983: 7, 11-12). Tyto myšlenky se týkají „jiného“, které je odlišné a vzdálené. Co se ale stane, pokud ,jiné“, které představuje předmět zkoumání, je součástí stejné společnosti a je stejně nazýváno? Rozptyl v prostoru se pak jeví jako rozptyl ve společenském prostoru, kde všichni představují domácí obyvatelstvo. A evoluční sled času, který je však hierarchický, se vrací k otázce, co je „jiné“ a o co jde $\mathrm{v}$ oborech antropologie, etnologie a etnografie.

\section{Institucionální trajektorie}

Všeobecně se má za to, že institucionální dějiny etnologie v Litvě začaly před druhou světovou válkou, kdy byla založena Katedra etnických studií (Etnikos katedra) na Univerzitě Vytautase Velkého v Kaunasu³ (1934) a Katedra etnologie a etnografie na Univerzitě Štěpána Báthoryho ve Vilniusu ${ }^{4}$ (1927) (viz též 
Čiubrinskas 2001; Apanavičius 2009). Katedra etnických studií v Kaunasu pořádala kurzy folkloristiky, mytologie, litevské literatury, historie litevského a lidového umění, prehistorie a archeologie - na tyto předměty se pohlíželo etnickým prizmatem se zvláštním zřetelem na folklor. V roce 1935 byl v Kaunasu založen Litevský folklorní archiv jako výzkumná instituce. Katedra etnologie a etnografie na Univerzitě Štěpána Báthoryho ve Vilniusu nabízela kurzy v oborech etnografie, výzkumných metod, polské a světové etnologie, filozofie, psychologie a prehistorie (Apanavičius 2009). Její akademické zájmy se zaměřovaly na etnologii s ohledem na kulturní historii, v tehdejší době však měla v litevské akademické oblasti omezený dopad.

Etnologie a etnografie zaujímala ve 20. a 30. letech 20. století pouze marginální institucionální pozici. Když došlo v roce 1939 ke sloučení oborů historie, lingvistiky a folkloristiky v rámci výzkumného Institutu litevských studií, byly etnologie a etnografie ponechány stranou. Etnologie či, přesněji řečeno, etnografie byla místo toho od roku 1934 přesunuta do provinční oblasti pod hlavičku Místní lidové společnosti a Muzea Aušra v Šiauliai. Muzeum organizovalo terénní etnografický výzkum a zajištovalo související publikační činnost v časopisu Gimtasai kraštas (Čepaitienè 2014). Až v roce 1941 se vědci působící na Univerzitě Vytautase Velkého, v Muzeu Aušra v Šiauliai a na Univerzitě Štěpána Báthoryho sloučili v rámci Etnologického institutu ve Vilniusu, který existoval do roku 1944 (Merkienė 2011).

Po druhé světové válce bylo záměrem udržet obor etnologie, nazývaný „etnografie“", na Vilniuské univerzitě při životě, tyto snahy však byly odsouzeny k nezdaru. Po celou sovětskou éru zůstala tato disciplína podoborem historie. Jednalo se pouze o jeden z předmětů pro studenty historie, podobně se folklor vyučoval jako součást litevské literatury a antropologie ve studijních plánech chyběla zcela s výjimkou fyzické antropologie, která představovala předmět v rámci medicíny. Etnografické dizertační práce, kterých bylo málo, se tehdy psaly v rámci oboru historie a často pod dohledem Etnografického ústavu N. N. Miklucho-Maklaje Akademie věd SSSR v Moskvě či Studií umění, etnografie a folkloru Akademie věd Běloruské SSR v Minsku (Šaknys 2004). Etnografický výzkum tradiční litevské lidové či de facto rolnické kultury, jejích hmotných forem, každodenního života a sovětského životního stylu byl provozován zejména v rámci Oddělení etnografie Historického ústavu Akademie věd Litevské SSR. „Patriotismus“ etnografư na tomto ústavu implicitně spočíval v zachování kontinuity meziválečné etnografické akademické tradice Muzea Aušra v Šiauliai a časopisu Gimtasai kraštas. V roce 1953 došlo k významnému disciplinárnímu oddělení etnografie a folkloristiky, přičemž archivní materiál byl rozdělen mezi Ústav litevského jazyka a literatury a Historický ústav. Folkloristé z Ústavu litevského jazyka a literatury zdědili téměř veškerý archivní materiál bývalé Litevské vědecké společnosti a Litevského folklorního archivu, zatímco etnografové na Historickém ústavu obdrželi jen malou část, která sestávala ze záznamů o názorech a přesvědčeních, na kterých se mělo dále 
pracovat. Ukázalo se však, že bylo nemožné pokračovat v tomto studiu pomocí stejné metodiky. Rozdělení archivů ve skutečnosti potvrdilo metodologický a epistemologický rozdíl mezi etnografií a folkloristikou. Od té doby etnografové z ústavu budovali etnografický archiv založený na terénním výzkumu a dotaznících (Šaknys 2011: 12). Po metodologické stránce představovala etnografie po celou sovětskou éru až do současnosti základ výzkumu, který je provozován v Oddělení etnografie. V roce 1996 bylo oddělení přejmenováno na Oddělení etnologie a v roce 2016 na Oddělení etnologie a antropologie.

K zásadním změnám v postojích $\mathrm{v}$ rámci této disciplíny došlo $\mathrm{v}$ souvislosti s nezávislostí Litvy v roce 1990 a reformou vědy a vzdělávání. Etnologie a antropologie získaly místo na univerzitách. Jako první byla v roce 1990 založena Katedra antropologie na Fakultě sociálních věd znovuotevřené Univerzity Vytautase Velkého v Kaunasu. Byla zř́izena za pomoci vědců z litevské diaspory v USA a studijní program vycházel z kulturní antropologie a jejích čtyř podoborů (Ciubrinskas 2015: 177-178). V roce 1993 však byla Katedra antropologie restrukturalizována na Katedru etnologie a folkloristiky na Fakultě humanitních věd, kde jako pedagogové působili etnologové z Litevského historického ústavu a folkloristé z Ústavu litevské literatury a folkloru. Nově zřízená katedra nabízela bakalářský studijní program v oboru etnologie, magisterský studijní program v etnických studiích a doktorandské studium v oboru etnologie $(07 \mathrm{H})$. Chtěla pokračovat v paradigmatické tradici etnických studií meziválečné Univerzity Vytautase Velkého (Apanavičius 2009). Avšak studijní program zahrnující folkloristiku, lidové umění, literární studia, etnografii, archeologii a etnomuzikologii byl doplněn o úvod do sociologie, fyzické a kulturní antropologie, světových kultur, kultury a osobnosti a religionistiky, přičemž většina těchto kurzů byla převzata $\mathrm{z}$ předchozího programu kulturní antropologie. Později byly nahrazeny předměty, jako jsou historie antických kultur, středověké studie, moderní filozofie a moderní historie, etnická kultura, komparativní studia kultury, současné etnické procesy, etnosociologie, kulturní teorie a kulturní studia, politické a sociální teorie a sémiotika. Disciplinární hranice etnologie (etnografie) a folkloristiky byly očividně pojaty velmi otevřeně. Předpokládalo se, že doplněním etnologických studií o předměty z antropologie, kulturních studií a historie, sociologie a religionistiky se rozšírí možnosti tohoto oboru (Apanavičius 2009). Když byly v roce 2012 na katedře zavedeny dva studijní programy zabývající se kulturou Pobaltí a kulturami a jazyky východní Asie, byla katedra přejmenována na Katedru kulturních studií a etnologie.

Proces institucionalizace ukazuje, že etnologie je interpretována jako interdisciplinární, transdisciplinární či multidisciplinární obor „seskupující dovednosti z různých perspektiv“ či mající „společný rámec sdílený napříč disciplínami, k němuž každá něčím přispívá“ (Strathern 2005: [127]). Její rámec spočívá na dvou aspektech zkoumaného objektu - na konceptu etnika a konceptu kultury, který sahá od antropologického pochopení až po sociologickou 
interpretaci, po aktivity spojené s uměním, či dokonce s aspektem „vzdělanosti“. Takové pojetí „kultury“ ponechává hranice široce otevřené, nejen pokud jde o různé konstelace předmětů, ale i o rozmanité metodologie. A etnologie je nadále vnímána jako „etnověda litevské kultury“, ačkoli z externího pohledu a pro některé možná i z hlediska interního tato disciplína a její předmět působí zastaralým, neuspořádaným a neproduktivním dojmem bez vazby na současný společenský život, aktuální témata a možnosti praktického uplatnění výsledků výzkumu (viz též Ciubrinskas 2015).

Od roku 1991 docházelo k pokusům etablovat antropologii na historické fakultě Vilniuské univerzity ve spolupráci se skandinávskými antropology z univerzit v Kodani a Lundu a za podpory litevské nadace Open Society Fund (Sorosovy nadace) a Severské rady ministrů (Ciubrinskas 2015: 178-179). V roce 1996 bylo založeno neformální Centrum sociální antropologie a etnologie. Kurzy antropologie, přednášky hostujících profesorů, výměnné programy pro studenty, každoročně organizované semináře a první Mezinárodní nordicko-baltická škola antropologie pro postgraduální studenty (1996) významně přispěly k rozvoji disciplíny, její popularitě mezi studenty a intelektuálnímu vlivu na etnology a historiky. Je třeba zdůraznit, že byla ve velkém měřítku posílena antropologizace etnologie (viz též Ciubrinskas 2015: 176-177). Bakalářský program v oboru kulturní historie a antropologie, jenž byl zaveden na Vilniuské univerzitě v roce 2001, funguje dodnes. Centrum na Vilniuské univerzitě však bylo v roce 2003 zrušeno a sociální antropologie byla přesunuta na Katedru sociologie na Univerzitě Vytautase Velkého. Tento institucionální přesun ve skutečnosti představoval změnu paradigmatu sociální antropologie od historie $\mathrm{k}$ sociologii. $\mathrm{V}$ roce 2004 byl na novém působišti založen magisterský program a v roce 2005 založeno Centrum sociální antropologie. Dodnes se jedná o jediný program sociální antropologie v zemi (Ciubrinskas 2015: 179-180). Kromě toho byl v roce 2013 založen bakalářský program pod názvem „Sociologie a antropologie“, ačkoli bakalářské tituly stejně jako dizertace spadají do sociologie. Mnoho absolventů má i obor sociální antropologie na Univerzitě Vytautase Velkého. Tato disciplína však dodnes není ve veřejné sféře téměř vidět a komentáře a pojednání z antropologického hlediska jsou ve srovnání se sociologií, historií či filozofií velmi vzácné. Zdá se, že veřejný image této disciplíny je i dnes stejný jako ve 20. a 30. letech 20. století antropologie je chápána jako studium primitivních a exotických společností. Pouze se v současnosti exotizace přesouvá od společností ke společenským a kulturním jevům.

Institucionální řešení 90 . let 20. století a první dekády tohoto století navozují jakousi disciplinární „brikoláž“ etnologie a antropologie jakožto multiči interdisciplinárních oborů, přičemž na etnologii se pohlíží v rámci univerzalistického způsobu myšlení, zatímco sociální antropologie jakožto součást sociologie koreluje například se sociálními tématy či demografií. Zdá se, že disciplinární jedinečnost pak je neformálně chráněna tradicí etnografického 
výzkumu. Podle Jiméneze zpo̊sob správy předává vědecké poznání, „uvádí ho ve známost“ a institucionalizuje ho (Jiménez 2007: 53). Instituce přebírají poznání jako akademickou činnost a jako předmět odrážející společenské potřeby, jenž je vhodný ke standardizaci, a vytvářejí vlastní konstelace. Vědecká politika se pak v procesu vymezování disciplíny a zakotvení institucionálních forem akademické činnosti celkově jeví neméně důležitá.

\section{Strategie, taxonomie a praxe}

Věda a vzdělání v Litvě prošly po strukturální a intelektuální stránce reorganizací v rámci postsovětské transformace, harmonizace s evropskými standardy a integrace. Národní strategie pro rozvoj vědy a technologie byla sladěna $\mathrm{s}$ vizí změnit společnost a ekonomiku směrem k inovativnímu, udržitelnému společenskému rozvoji založenému na znalostech. Bylo zdůrazňováno, že technologický pokrok a inovace jsou jádrem ekonomického a kulturního pokroku, který mění kvalitu života, a strategie zaměřená na rozvoj výzkumu a technologie tvoří zásadní složku národního rozvoje obecně (litevská Bílá kniha vědy a technologie 2002). Tvůrci politiky v oblasti společenských a humanitních věd však věnovali pozornost tomu, aby ústřední kategorii a koncepci litevské politiky v oblasti vědy tvořil vědecký výzkum a experimentální vývoj (moksliniai tyrimai ir eksperimentine plètra), přičemž se jedná o přímý překlad formulace z Frascati manuálu, 2002, Organizace pro hospodářskou spolupráci a rozvoj (OECD) (Viliūnas 2004b: 48). Všeobecný model obsažený v politice OECD klade důraz na rozvoj přírodních věd a technických oborů, společenským vědám připisuje druhotné postavení a humanitním oborům okrajové místo na úrovni servisních činností (Viliūnas 2004b). Kouzlo vyspělých technologií obklopuje i vědu v Litvě. Technologický pokrok a modernita se jeví jako vlivné faktory, které mají dopad na společenské a politické hodnocení vědy, taxonomické vztahy mezi jednotlivými obory a jejich praktický rozvoj. Neméně důležité je však mezinárodní uznání akademické činnosti.

$\mathrm{V}$ roce 2013 skupina etnologů v Litvě vypracovala popis etnologie a folkloristiky. Po schválení v podobě vyhlášky ministerstva školství a vědy se tento popis stane oficiálním dokumentem, který institucionalizuje daný obor a pomůže vysokým školám a univerzitám při vytváření a aktualizaci studijních programů a hodnocení jejich kvality. Tento postup je v souladu s klasifikačním systémem studií, který poskytuje standardy pro správu a řízení institucí a studijních programů. Mezi řadou připomínek k tomuto popisu se vyskytla poznámka, která kriticky hodnotila hlavní koncepci a uváděla, že založení studijních oborů etnologie a folkloristiky je umělé a nemotivované, jelikož taková klasifikace není založena na žádných mezinárodních dokumentech a v mezinárodní klasifikaci neexistuje. Uvádělo se v ní, že výzkum v této oblasti v Litvě tradičně provozují týmy specialistů z různých disciplín. 
Klasifikační systémy vědy či studií poskytují normativní standardizaci vědy, jejích oblastí a podoblastí a uvádějí ji do vztahu s mezinárodní konceptualizací a národní akademickou sférou. Odůvodňují jedinečnost poznání, metodologie a teorie a jsou nástroji pro správu vědy v jejím jádru i na úrovni řízení a financování. Vplývají do nich a zároveň z nich vyplývají společenské vztahy (Jiménez 2007: 53). Zdá se, že klasifikační systémy jsou poměrně jednotné, stabilní a harmonizované výstupy, které vznikly v souladu s všeobecným pojetím vědy. Existují však různé mezinárodní a národní systematizace. Nenajdeme žádné dva identické systémy, stejně jako neexistují dva stejné seznamy antropologie a jejích podoblastí (Ingold 2015: 341-342). Systémy se liší podle ideje, účelu a kritérií, která každý systém využívá. Kromě toho se systémy mění, bývají v průběhu času revidovány podle potřeb společnosti a v závislosti na rozvoji věd.

Pokud jde o hlavní formy systematizace, Litva prioritně využívá přístupy navržené mezinárodně uznávanou metodikou OECD a Evropskou výzkumnou radou (ERC), ačkoli jsou velmi odlišné. Ani jeden z nich nevychází z disciplinárního spojení etnologie a folkloristiky. Nejnovější verze revidované Klasifikace oblastí vědy a technologií (Frascati manuál, OECD 2007) zařazuje etnologii a folklorní studia do různých oborů společenských a humanitních věd. Obor etnologie řadí společně s antropologií do podoblasti 5.4. Sociologie v rámci oblasti 5. Společenské vědy, zatímco folklorní studie jsou zařazeny do podoblasti 6.4. Umění spadající pod oblast 6 . Humanitní vědy. Poslední vydání Frascati manuálu z roku 2015 (OECD 2015: 59), které obsahuje pouze seznam oblastí výzkumu a vývoje, neuvádí etnologii ani antropologii či folklorní studia. Pro takové řekněme nepředvídatelné případy slouží položky „5.9. Další společenská studia“ či „6.5. Další humanitní vědy“.

Je evidentní, že národní strategie a systematizace si zachovávají význam pro definici a institucionalizaci disciplín. V Litvě existují dva hlavní systémy - jednak již zmíněná klasifikace studií platná pro instituce a studijní programy, jednak klasifikace věd aplikovatelná na instituce, výzkum a doktorandské studium. Je-li určitý obor zařazen do jednoho z těchto systémů, má pozici studijního programu či výzkumné oblasti s institucionálními možnostmi a šancemi na financování. Klasifikace definují byrokratickou hranici určitého oboru, taxonomické vztahy mezi obory a podobory a poskytují standardy pro řízení, financování a stanovení odpovědností.

Podle aktuálního seznamu Klasifikace oblastí vědy, 2012, který byl podepsán jako vyhláška ministerstva školství a vědy, je etnologie $(07 \mathrm{H})$ považována za nezávislý obor humanitních věd. Má místo srovnatelné s historií $(05 \mathrm{H})$, filologií $(04 \mathrm{H})$, filozofií $(01 \mathrm{H})$ či uměním $(03 \mathrm{H})$. Z institucionálního hlediska by etnologie mohla nalézat uplatnění na třech úrovních vzdělávání včetně bakalářských, magisterských, doktorandských a výzkumných programů. Antropologie však jako samostatný obor na seznamu chybí. Vycházíme-li z předchozího klasifikačního systému z roku 1998, můžeme předpokládat, že 
antropologie je nadále podoborem sociologie (05S), která je spolu s etnologií zahrnuta pod názvem „kulturní antropologie a etnologie“(S220). Klasifikační systém z roku 1998 rovněž poskytuje více informací o složení oboru etnologie (07H). Ukazuje, že etnologie se skládá z podoborů, jako je regionální historie, historický zeměpis počínaje středověkem, archeologie a prehistorie, historie umění, muzikologie a divadelní studie, onomastika a folkloristika. Všechny tyto podobory však náležejí do jiných oborů a metodologií, jako je historie, umění či filologie. Očividně neexistuje žádný konkrétní podobor etnologie, který by vyjadřoval její metodickou a teoretickou jedinečnost.

Je třeba zdůraznit, že klasifikační zařazení oborů etnologie a antropologie v národní dokumentaci vědy ponechává tyto obory v jakémsi meziprostoru. To odpovídá i jejich akademickému a veřejnému postavení. Jejich individualita je popsána a vyložena pouze ve strategii pro rozvoj sociálních a humanitních věd z roku 2004 (Viliūnas 2004a). Antropologie, etnologie a folkloristika jsou zde klasifikovány jako tři z devatenácti oborů společenských a humanitních věd. Jsou konceptualizovány a popsány jako oblasti s různou historií, institucemi, odlišným tematickým přístupem a výhledem do budoucna (Čiubrinskas 2004; Šaknys 2004; Sauka - Stundžienè 2004). A jejich definice nadále obsahují body, které otevírají prostor pro negaci, interdisciplinární úvahy či konstelace.

Antropologové při diskusi o otázkách institucionalizace a vymezení disciplíny často zdůrazňují vlastní odpovědnosti a interní perspektivy. Neméně důležité jsou však byrokratické formality a externí oficiální úvahy. Formální hlediska určují institucionální podobu jednotlivých oborů, zajištují možnosti pro poskytování finančních prostředků, vytvářejí pracovní a studijní místa, definují vztahy mezi obory či formulují př́istupy k aplikovatelnosti daného oboru. Celkově se však rozvoj epistemologie obrací na vědecké komunity jako „kolektivy myšlení“ (od Flecka, viz Edwards - Harvey - Wade 2007) a zdůrazňuje významnou měrou aspekt praktického uplatnění výsledků výzkumu. Setkání se způsoby, jakými je epistemologie pojata, poukazují na komplexnost perspektiv, které obklopují etnologické a antropologické prrístupy a poznatky.

\section{Závěr: metodologická hodnota etnografie}

Algirdas Julius Greimas jednou řekl, že „,věda začíná definováním svého předmětu a rozvojem metod, nikoli náhodně shromážděnými daty“ (Greimas 1979: 15; viz též Čiubrinskas 2001). V případě etnologie a antropologie v zásadě reprezentuje metody a metodologii etnografie. Antropologové hodnotí literární schopnosti etnografie a její jazykové schopnosti pro prezentaci textu a popisu a postulují ji jako jedinečnou metodu a metodologii (např. Hammersley 2001; Clifford 2005: 38). Ingold naopak vymezuje etnografii a antropologii jako různé stavy bytí (Ingold 2008; 2014). Avšak bez etnografie jako metody a vědecké praxe zůstává etnologie a antropologie pouhým textem, diskurzem, literaturou či, jak se v Litvě často rríká, „filozofií“, nestane se však epistemologií, 
která přistupuje k lidské realitě in situ v rámci její mikrokomplexnosti a různorodých perspektiv. Na otázku „[j]ak jste si vědoma interdisciplinarity ve vaší dráze? Je to něco, o co jste vědomě usilovala?“ Strathernová odpovídá „[n]e! Předpokládám, že to, co dělám, je antropologie. Ale vaše otázka mě přivedla k zamyšlení. Mám etnografický přístup k diskusím, které pocházejí z jiných disciplín - ve všech př́ípadech se jedná o produkty určité kultury či společnosti - a používám je jako zdrojové materiály“ (Strathern 2005: 128).

Ačkoli je etnologické a antropologické dědictví v Litvě roztřrištěné a malé, poskytuje informace o utváření své paradigmatické tradice. Jeho historická cesta ukázala, že etnologická a antropologická zvídavost prošla zvraty a nepokoji historických světů díky specifické praxi shromažd'ování poznatků. Základní rozlišení mezi člověkem s běžným pozorováním a člověkem s pozorováním vědeckým, které bylo vypracováno na sklonku 18. a na počátku 19. století, představovalo heuristickou událost, která otevřela epistemologickou perspektivu do budoucna. Kdykoli se v Litvě přistupovalo ke kulturním úvahám o lidských fenoménech, hrála při vytváření tohoto konkrétního poznání roli etnografie uplatňující vědecké pozorování (a shromažd’ování). Historie ukazuje, že etnografie jako metoda a metodologie je neoddělitelná od paradigmatické jedinečnosti a intelektuálního potenciálu etnologie a antropologie ve vědeckém spektru.

Květen 2016

\section{Literatura}

Apanavičius, Romualdas. 2009. Etnologijos studijos Lietuvoje 1927-2005 metais. Lietuvos etnologija: socialinés antropologijos ir etnologijos studijos 9, 18: 139-164.

Berdahl, Daphne. 2000. Introduction: An Anthropology of Postsocialism. In:

Berdahl, D. - Bunzl, M. - Lampland, M. (eds.): Altering States: Ethnographies of Transition in Eastern Europe and the Former Soviet Unijon. Ann Arbor: The University of Michigan Press: 1-13.

Būtènas, Petras. 1925. Lietuviu tautotyros žiniu ir senieny rinkimo programa. Šiauliai: „Vilties“ draugijos leidinys. Ciubrinskas, Vytis. 2015. Contested Disciplines in New Europe: Ethnology and Sociocultural Anthropology in Lithuania. In: Adam, B. - Retka, T. (eds): Rytî́ z Komárova: $K$ 70. narozeninám Petra Skalníka / Knight from Komárov:
To Petr Skalník for his 70th birthday. Praha: AntropoWeb: 171-185.

Clifford, James. 2005. Rearticulating Anthropology. In: Segal, D. A. - Yanagisako, S. J. (eds.): Unwrapping the Sacred Bundle: Reflections on the Disciplining of Anthropology. Durham and London: Duke University Press: 24-48.

Čepaitienè, Auksuolè. 2011. Etnologijos (etnografijos) ištakos ir valstiečio atradimas Lietuvoje XVIII a. pabaigoje - XIX a. pradžioje. Lietuvos etnologija: socialines antropologijos ir etnologijos studijos 11, 20: 69-91.

Čepaitienè, Auksuolè. 2014. Etnografija Lietuvoje: praktika ir (ar) teorija. XX a. tarpukario kontekstai. In: Savoniakaitè, V. (ed.): Savas ir kitas šiuolaikiniais požiūriais/Contemporary Approaches to the Self and the Other. Vilnius: LII leidykla: 367-394. 
Čiubrinskas, Vytis. 2001. Sovietmečio iššūkiai Lietuvos etnologija: disciplina, ideologija ir patriotizmas. Lietuvos etnologija: socialines antropologijos ir etnologijos studijos 1, 10: 99-117.

Čiubrinskas, Vytis. 2004. Antropologija. In: Viliūnas, G. (ed.): Lietuvos humanitariniu ir socialiniu moksly plètros problemos. Vilnius: LII leidykla: 61-70.

Dundulienè, Pranè. 1978. Etnografijos mokslas Vilniaus universitete. Vilnius: LTSR aukštojo ir specialiojo vidurinio mokslo ministerija.

Edwards, Jeanette - Harvey, Penny - Wade, Peter. 2007. Introduction: Epistemologies in Practise. In: Edwards, J. - Harvey, P. - Wade, P. (eds): Anthropology and Science: Epistemologies in Practise. Oxford and New York: Berg: 1-18.

Endziulaitytè-Gylienè, M. 1926. Antropologija ir jos pritaikimas. Kosmos 4-5: 157-162.

Eriksen, Thomas Hylland - Nielsen, Finn Sivert. 2001. A History of Anthropology. London: PlutoPress.

Fabian, Johannes. 1983. Time and the Other: How Anthropology Makes Its Object. New York: Columbia University Press.

Gow, Peter. 2009. The Ontogeny of an Anthropological Epistemology in Eighteenth Century Scotland. Social Analysis 53, 2: 19-39.

Greimas, Algirdas J. 1979. Apie dievus ir žmones: lietuvių mitologijos studijos. Chicago: Algimanto Mackaus knygų leidimo fondas. Hammersley, Martyn. 2001. What's Wrong with Ethnography? Methodological Explorations. London and New York: Routledge.

Hann, Cris et al. 2007.

Anthropology's Multiple Temporalities and Its Future in Central and eastern Europe. A Debate. Working Paper No. 90. Halle/Saale: Max Planck Institute for Social Anthropology. Ingold, Tim. 2008. Anthropology is Not Ethnography. Proceedings of the British Academy 154: 69-92.

Ingold, Tim. 2014. That's enough about ethnography! HAU: Journal of Ethnographic Theory 4, 1: 383395. [2016-04-26] Dostupné z: http:// dz.doi.org/10.14318/hau4.1.021. Ingold, Tim. 2015. Rethinking EuroAnthropology. Social Anthropology/ Anthropologie Sociale 23, 3: 341-342. Jasinski, Józef. 1818. Antropologia o własnościach człowieka fizycznych i moralnych. Wilno: Nakładem i drukiem Józefa Zawadzkiego typografa Imperatorskiego uniwersytetu.

Jiménez, Alberto Corsín. 2007. Industry Going Public: Rethinking Knowledge and Administration. In: Edwards, J. - Harvey, P. - Wade, P. (eds): Anthropology and Science: Epistemologies in Practise. Oxford and New York: Berg: 39-57. Jučas, Mečislovas. 1997. Istoriografija Vilniaus universitete 1803-1832 m.: tarp Švietimo ir Romantizmo. Lietuvos istorijos studijos 4: 92-102.

Klimas, Petras. 1917. Etnografinio désnio reikšmè. Lietuvos aidas 27.11.1917, 29.11.1917, 01.12.1917, 04.12.1917. Končius, Ignas. 1934. Gimtojo krašto pažinimas. Gimtasai kraštas 1: 3-6. Kudaba, Česlovas. 1988. Žymus XVIII a. gamtininkas Georgas Forsteris. In: Kilius, J. (ed.): Georgo Forsterio laiškai iš Vilniaus. Vilnius: Mokslas: 7-23.

Lelewel, Ioachim. 1815. Historyka tudzież o łatwem i pożytecznem nauczaniu historyi. Wilno: Drukarnia XX Pijarow.

Lelewel, Joachim. 1964. Dziela: Pisma metodologiczne 2(1). Warszawa: Panstwowe wydawnictwo naukowe.

Leonas, Petras. 1995 [1939]. Sociologijos paskaitos. Vilnius: Pozicija.

Lithuanian Science and Technology White Paper. 2002. Vilnius: Department of Science and Higher Education under The Ministry of Education and Science of the republic of Lithuania.

Maciūnas, Vincas. 1939. Lituanistinis sajūdis XIX amžiaus pradžioje: susidomejjimas lietuvių kalba, istorija ir tautotyra. Darbai ir dienos 8: 3-344.

Merkienè, Irena Regina. 2011. Etnologijos institutas sovietmečio Lietuvoje mokslo politikos ir ideologijos kontekste. Lietuvos 
etnologija: socialines antropologijos ir etnologijos studijos 11, 20: 125-142.

Milius, Vacys. 1993. Mokslo draugijos ir lietuviu etnografija (XIX a. antroji puse - XX a. pirmoji pusé). Vilnius: Mokslo ir enciklopediju leidykla. Norkus, Zenonas. 2015. Two Hundred Years of the Theory of Historiography in Lithuania, or How Joachim Lelewel Became the Pioneer of Modern Comparative History, Sociologija. Mintis ir veiksmas 1, 36: 5-31.

OECD. 2015. Frascati Manual 2015: Guidelines for Collecting and Reporting Data on Research and Experimental Development. The Measurement of Scientific, Technological and Innovation Activities. Paris: OECD Publishing. [2016-05-16] Dostupné z: http://dx.doi. org/10.1787/9789264239012-en.

Posern-Zieliński, Aleksander. 1995. Etnologia i antropologia kulturowa w formalnej i rzeczywistej strukturze nauki. In: Posern-Zieliński, A. (ed.): Etnologia Polska między ludoznawstwem a antropologiq. Poznań: Wydawnictwo DRAWA: 21-36.

Sauka, Leonardas - Stundžienè, Bronè. 2004. Tautosakos mokslas. In: Viliūnas, G. (ed.): Lietuvos humanitariniu ir socialiniu moksly plètros problemos. Vilnius: LII leidykla: 134-140.

Savoniakaitè, Vida. 2008a. Apie Lietuvos etnologijos istoriją. Lituanistica 3: 59-66.

Savoniakaitè, Vida. 2008b. Lietuvos etnografija tarp savos kultūros tyrimu. Lituanistica 4: 61-72.

Spiro, Melford E. 1991. On The Strange and the Familiar in Recent Anthropological Thought. Reprinted with permission from Transaction Publishers from the journal 'Anthropological Other or Burmese Brother'. [2016-03-15] Dostupné z: http://wps.prenhall.com/ wps/media/objects/12330/12626747/ myanthropologylibrary/PDF/ NDS_122_Spiro_121.pdf.

Stocking, Georg W. 1992. The Ethnographer's Magic and Other Essays in the History of Anthropology. Madison and London: The University of Wisconsin Press.
Strathern, Marilyn. 2005. Anthropology and Interdisciplinarity. Arts and Humanities in Higher Education 4, 2: 125-135.

Šaknys, Žilvytis. 2004. Etnologija. In: Viliūnas, G. (ed.): Lietuvos humanitariniu ir socialiniu moksly plètros problemos. Vilnius: LII leidykla: 117-125.

Šaknys, Žilvytis. 2011. Ieškant idejju praeityje: etnologijos istorija ir dabartis. Lietuvos etnologija: socialinés antropologijos ir etnologijos studijos 11, 20: 9-32.

Šernas [Adomaitis Juozas] (ed.). 1903. Ethnologija arba mokslas apie žemés tautas. Pagal Dr-q M. Haberlandta ir Letourneau. Chicago: Turtu ir spauda "Lietuvos".

Švambarytè, Dalia. 2009. Georg Forster in Vilnius: Reverberations of the great age of ocean navigation. Acta Orientalia Vilnensia 10, 1-2: 139-164.

[Szydłowski Ignacy]. 1819. Obrzędy weselne ludu wieyskiego w gubernii mińskiey, w powiecie borysowskim w parafini haieńskiey, obserwowane w latach 1800, 1szym i 2gim, z niektóremi piosnkami I ich zwyczayną notą. Zamówiny. Tygodnik Wileński 7, 132: 81-104.

Tunaitis, Steponas. 2004. Apšvietos epochos socialinès ir politinès filosofijos metmenys. Vilnius: Kultūros, filosofijos ir meno institutas.

Viliūnas, Giedrius (ed.). 2004a. Lietuvos humanitariniy ir socialinių moksly plètros problemos. Vilnius: LII leidykla.

Viliūnas, Giedrius. 2004b. Humanitariniai ir socialiniai mokslai šiandieninèje Lietuvos mokslo politikoje: In: Viliūnas, G. (ed.): Lietuvos humanitariniu ir socialiniu moksly plètros problemos. Vilnius: LII leidykla: 48-51.

Wyngaard, Amy S. 2004. From Savage to Citizen: The Invention of the Peasant in the French Enlightenment. Newark: University of Delaware Press. 